\title{
HANUMANTE RIVER: EMERGING USES, COMPETITION AND IMPLICATIONS
}

\author{
Rajesh Sada \\ Research Coordinator, Peri-urban Water Security Project, \\ Nepal Engineering College-Center for Postgraduate Studies
}

\begin{abstract}
This paper describes the existing uses and competition over Hanumante River water and its implications to the river ecology. The study was completed by conducting in-depth review of literatures, key-informants' interview and semi-structured interview. The major water extraction in the Hanumante River is through 148 community drinking water supply schemes which is estimated to extract 15.6 million litres of water per day. Besides this, there are 127 irrigation systems with cumulative command area of 5174 ha in wet season and 42 brick industries using 142 million litres of water annually directly from Hanumante River, leaving very little water to flow downstream reaches. Moreover, there are hundreds of water pumps used for water extraction from river for irrigation purpose. The water flow on the downstream is essentially sewage flow and liquid wastewater disposal into the river and limited groundwater contributions. In addition, there are 232 industries in the city of Bhaktapur, most of which, although, do not extract river water directly, the effluents produced in these industries are discharged into the river either directly or through municipal sewerage system. In order to maintain the healthy river ecology, minimum environmental flow should be maintained in the river.
\end{abstract}

Keywords: Hanumante River, Water, Uses, Competitions, Implications

\section{Introduction}

The Hanumante is an important tributary of the Bagmati River with a catchment area of 143 $\mathrm{km}^{2}$. The river course covers $3.92 \%$ of the area of the Bhaktapur and Madhyapur Thimi municipalities (Pant and Dongol, 2009). Major sources of water in Hanumante River are rainfall and natural springs. This has been the major natural waterway in Bhaktapur district which has its origin in Mahadev Pokhari at Nagarkot. It flows through the rural and urban areas of Bhaktapur district before joining Manohara River at Jadibuti in Kathmandu. Hanumante River has been important to the people in Bhaktapur and in its neighborhood for cultural, ecological and economic reasons. Several places of cultural and religious importance are located

*Corresponding author: Rajesh Sada,

Research Coordinator, Peri-urban Water Security Project, Nepal Engineering College-Center for Postgraduate Studies Contact: 00977-9751041822, Email: rajeshs@nec.edu.np (Received date: 2011 Aug 03 Accepted date: 2011 Nov 7) along the course of Hanumante River, which include Hanumanghat, Maheshworighat, Chupinghat, Mangal Tirtha. There are also several temples built along the banks of Hanumante River, some of which are very old and have religious and archeological importance. Hardly twenty years back, people living in Bhaktapur and its neighborhood used to bathe, swim and even drink water from Hanumante. The river has now turned into a virtual sewerage. The river is getting polluted since entire sewage of Bhaktapur and Thimi municipalities and industrial wastes are directly drained into river without any treatment whatsoever. Though religious people still do bathe in the river, most people however restrain from using the river water. The religious and cultural value of river has been continuously eroding due to pollution and degradation in the water quality and there has been no initiative on river conservation to date. 
Almost 30 years back, there was not a practice of sewerage system and industrial effluents directly discharged into river. During water scarcity period or dry season, there was a practice of digging a hole in a river and collect sub-surface flow water. As water level is high in river section, water was easily collected which was then used for irrigation. But now, there is only the flow of polluted water or sewage in the river during dry season which is used for irrigation. This sewage flow in the river not only has negative health impacts on the wastewater irrigators, but also stinks while walking by the side of the river, resulting in the degradation of river and surrounding environment as well.

The river gets almost dry, even to half of its course up to Hanumanghat, which has been, due to the upstream withdrawal by numerous brick factories, industries and for domestic and agricultural water uses on the upstream. On the downstream of Hanumanghat, disposal of solid and liquid wastes and encroachment upon the river water course have been the major causes of river degradation.

Though pollution in Hanumante River progressively increases beyond Hanumanghat, people continue to use this water for different purposes. While cultural and religious uses of river have been very important, the use of river water has also been significant from the point of view of economy and livelihood of the people living along the river course. Use of wastewater for irrigation has been one of such uses which have been intensifying around Bhaktapur. This is increasingly becoming important use of water from Hanumante, supporting the livelihood of farmers who are engaged in the production of vegetables in the area.

\section{Study Area}

\subsection{Bhaktapur}

This study was carried out in Bhaktapur district of Hanumante river basin which covers an area of $119 \mathrm{sq} . \mathrm{km}$ and comprises of two municipalities viz. Bhaktapur Municipality (6.88 sq. km) and Madhyapur Thimi Municipality (11.47 sq. km) and 16 Village Development Committees. The total population of the district is about 2 , 25,461 .

Bhaktapur extends from $27^{\circ} 36^{\prime}$ to $27^{\circ} 44^{\prime}$ North latitude and $85^{\circ} 21^{\prime}$ to $85^{\circ} 32^{\prime}$ East longitude having a total length of $16 \mathrm{~km}$ from east to west. Its elevation ranges from $1300 \mathrm{~m}$ above sea level to $2191 \mathrm{~m}$ above mean sea level. The district experiences sub-tropical to temperate climate with an average annual rainfall of $1600 \mathrm{~mm}$. During summer season it reaches the maximum temperature of 32ÚÆC, whereas during winter it reaches a minimum temperature upto -2ÚÆC (DDC, Bhaktapur).

\subsection{Hanumante River}

Hanumante is the major river system and also major water source in Bhaktapur which has its own ecological, economic, cultural and religious importance. The river originates from Mahadev Pokhari at Nagarkot (Mahabharat hill) and passes through Bhaktapur and Thimi municipalities before joining Manohara River at Jadibuti in Kathmandu. It flows from north-east to south-west having average width ranging from minimum $10 \mathrm{~m}$ to maximum $20 \mathrm{~m}$. The total stretch of the river course is $23.5 \mathrm{~km}$ with total catchment area of $143 \mathrm{~km}^{2}$. Of these, $100 \mathrm{~km}^{2}$ is located in the Bhaktapur district and the rest, about $43 \mathrm{~km}^{2}$ falls in Patan District (nec, 2008). The river includes numerous tributaries forming several subbasins.

The Hanumante basin encompasses a total of 24 VDCs in Bhaktapur and Lalitpur Districts and also includes Bhaktapur and Thimi municipalities.

\section{Methodology}

\subsection{Key-Informants' Interview}

Apart from gathering information from personnel engaged in government institutions relating to surface water use, such as, Department of Irrigation, National Federation for Irrigation Water Users Association of Nepal, Drinking Water Supply and Sanitation Division Office, Kathmandu Upatyaka 


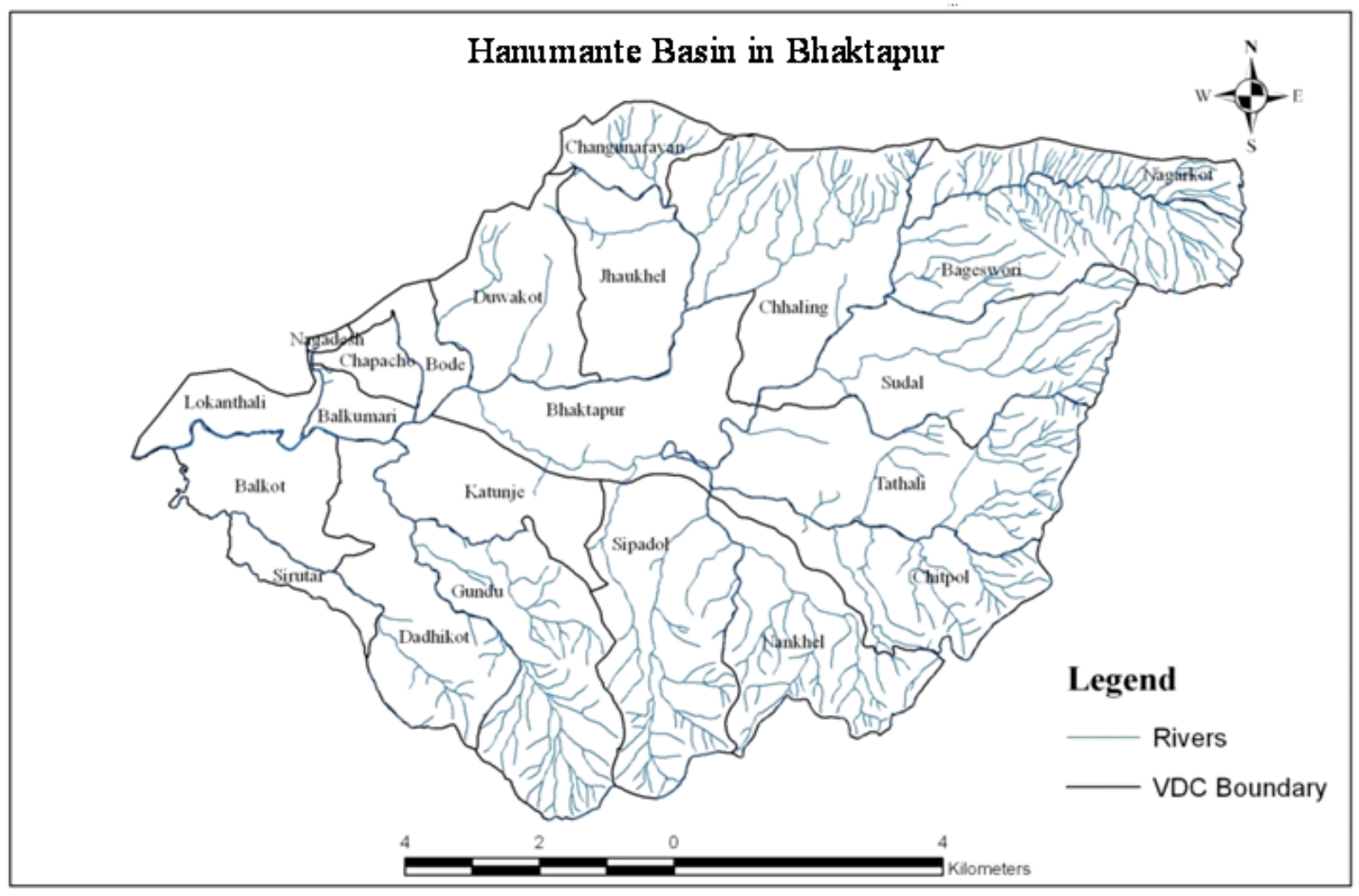

Fig.1. Study Site

Khanepani Ltd. (KUKL), District Agricultural Development Office and Irrigation Division Office, persons representing different sections of society, such as, political leaders, social activists and elderly citizens were interviewed. Key-informants' interviews were primarily focused on assessing changes in the river water use, number of existing drinking water supply schemes and irrigation schemes which withdraw water from river and its tributaries. Altogether 95 key informants were interviewed from different locations of the study area (Table 1).

In accounting the existing water use from Hanumante River, the names of the drinking water schemes, their locations, water withdrawal per day and number of households served under each scheme were collected. Similarly, for irrigation water use, name of the irrigation schemes withdrawing water from the river, their location and the area served during wet and dry seasons were collected.
Table 1: Number of Key Informants interviewed by

\section{Location}

\begin{tabular}{|c|l|c|}
\hline S.N. & Village Name & $\begin{array}{c}\text { Number of Key } \\
\text { informants }\end{array}$ \\
1 & Sudal & 5 \\
\hline 2 & Bageshwori & 6 \\
\hline 3 & Chaling & 3 \\
\hline 4 & Tathali & 8 \\
\hline 5 & Nagarkot & 3 \\
\hline 6 & Chittapol & 4 \\
\hline 7 & Nangkhel & 5 \\
\hline 8 & Seepadol & 10 \\
\hline 9 & Gundu & 9 \\
\hline 10 & Katunje & 4 \\
\hline 11 & Dadhikot & 12 \\
\hline 12 & Balkot & 5 \\
\hline 13 & Sirutar & 7 \\
\hline 14 & Duwakot & 6 \\
\hline 15 & Jhaukhel & 2 \\
\hline 16 & Bhaktapur Municipality & 95 \\
\hline & & Total \\
\hline
\end{tabular}




\subsection{Semi-structured Interview}

The information on annual brick production and water consumption by brick industries was collected through semi-structured interview with the entrepreneurs of the brick factories.

\subsection{Secondary Data Collection}

The secondary data needed in the course of the study were collected from published and unpublished sources. Relevant data were obtained from government and non-government offices such as, District Development Committee (DDC), Municipalities, Department of Irrigation (DoI), Kathmandu Upatyaka Khanepani Limited (KUKL), GTZ, ICIMOD, Ministry of Water Resources and Department of Survey.

\section{Results and Discussion}

\subsection{Water Use, Extraction and Competition in Hanumante River}

The water in Hanumante River is used for different purposes. In the upstream reaches of Hanumante River and its tributaries, water is used for domestic uses and for irrigation. There are altogether 148 community managed drinking water schemes in Bhaktapur, other than those under Kathmandu Upatyaka Khanepani Limited at Bhaktapur and Thimi Municipalities. The water consumption in these schemes including KUKL, based on the estimate made from the nature of the water supply schemes and the population served by them is estimated to be 15,639,200 litres per day. According to 2001 census, the population of Bhaktapur district was 225461, which if divided by the estimated consumed amount of water in Bhaktapur, the per capita per day (LPCD) water consumption will be 69 litres.

Similarly, there are 127 irrigation schemes in Hanumante River basin in Bhaktapur district, with cumulative command area of 101,715 ropanies (5173.7 ha) during monsoon though the irrigation coverage during dry season is estimated to be 44,050 ropanies (2241 ha). A list of the community drinking water schemes and the irrigation schemes deriving their supplies from Hanumante River and its tributaries, by VDCs, is provided in Table 2. The irrigation inventory of Bhaktapur carried out by DoI/ ADB in 2008, has estimated the total irrigated land in Bhaktapur district to be 5,526 ha while in the global map of irrigated areas prepared by FAO, the irrigated area in Bhaktapur has been estimated to be 2,588 ha. Besides diverting river water for irrigation at different locations by building temporary brushwood diversion structures, people also pump river water using low lift centrifugal pumps to irrigate land along the river courses. Pump users are generally those farmers who are involved in commercial vegetable cultivation in the fringe area of the city of Bhaktapur. It is though difficult to ascertain the exact number of pumps used by the farmers at different locations, however more than 100 pumps are estimated to be used by the farmers in pumping water from Hanumante River at different locations.

Brick industries have also been extracting significant amount of water from the river. The total number of brick industries in Hanumante River basin within Bhaktapur district is 63. Among 63 brick industries in the area, 21 of them are extracting groundwater to meet their daily water needs. All these industries have developed their own deep tube wells. Rests of the industries (about 42 in number) are using water directly from the Hanumante River and its tributaries. Of these 42 brick industries, 3 industries also occasionally depend on the water tanker based supplies to meet the deficit water needs. The total water consumption of the brick industries in Bhaktapur, disregarding the source of water, is estimated to be $208,080,000$ litres per year. Of this demand, the annual extraction of water solely

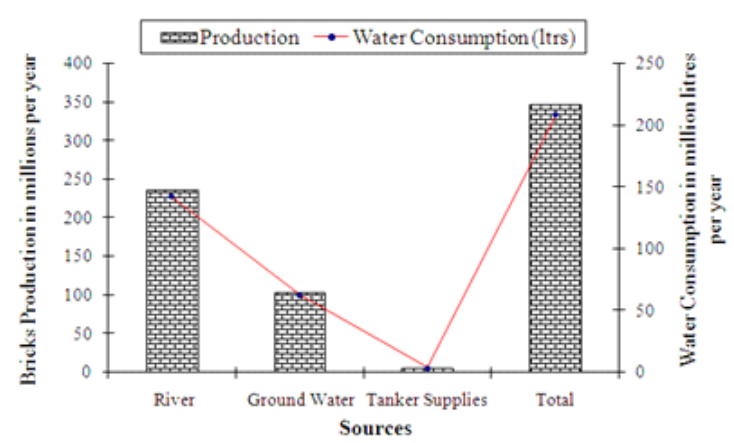

Fig.2.: Bricks Production and their Water Consumption in Bhaktapur 
Table 2: Summary of drinking water and irrigation schemes in Bhaktapur district

\begin{tabular}{|c|c|c|c|c|c|c|c|c|c|c|}
\hline \multirow{3}{*}{$\begin{array}{l}\text { S. } \\
\text { No. }\end{array}$} & \multirow{3}{*}{ VDC Name } & \multicolumn{3}{|c|}{ Drinking Water Schemes } & \multicolumn{6}{|c|}{ Irrigation Schemes } \\
\hline & & \multirow{2}{*}{ No. } & \multirow{2}{*}{ Sources } & \multirow{2}{*}{$\begin{array}{c}\text { Total water } \\
\text { consumption } \\
\text { (litres per } \\
\text { day) }\end{array}$} & \multirow{2}{*}{ No. } & \multirow{2}{*}{ Sources } & \multirow{2}{*}{\multicolumn{2}{|c|}{$\begin{array}{l}\text { Type of } \\
\text { Source }\end{array}$}} & \multicolumn{2}{|c|}{$\begin{array}{l}\text { Total area of land } \\
\text { irrigated (Ropani) }\end{array}$} \\
\hline & & & & & & & & & Wet & Dry \\
\hline 1 & Seepadol & 9 & $\begin{array}{c}\text { Springs, } \\
\text { Streams and } \\
\text { Stone spouts }\end{array}$ & 375000 & 14 & $\begin{array}{l}\text { Streams } \\
\text { and } \\
\text { Stone } \\
\text { spouts }\end{array}$ & \multicolumn{2}{|c|}{ Perennial } & 7500 & 3875 \\
\hline 2 & Sirutar & 5 & $\begin{array}{c}\text { Springs, } \\
\text { Streams and } \\
\text { Ground water }\end{array}$ & 290000 & 3 & Streams & \multicolumn{2}{|c|}{ Perennial } & 1000 & 550 \\
\hline 3 & Nangkhel & 7 & $\begin{array}{l}\text { Streams and } \\
\text { Springs }\end{array}$ & 200000 & 17 & Streams & \multicolumn{2}{|c|}{ Perennial } & 8700 & 3250 \\
\hline 4 & Jhaukhel & 7 & Tube well & 35700 & 6 & Streams & \multicolumn{2}{|c|}{$\begin{array}{l}\text { Perennial } \\
\text { and } \\
\text { Seasonal }\end{array}$} & 1370 & 1220 \\
\hline 5 & Dadhikot & 7 & $\begin{array}{l}\text { Springs and } \\
\text { Boring }\end{array}$ & 680000 & 7 & $\begin{array}{l}\text { Streams } \\
\text { and } \\
\text { Stone } \\
\text { spouts }\end{array}$ & \multicolumn{2}{|c|}{$\begin{array}{l}\text { Perennial } \\
\text { and } \\
\text { Seasonal }\end{array}$} & 19900 & 6745 \\
\hline 6 & Duwakot & 4 & Boring & 115000 & 0 & - & & - & 0 & 0 \\
\hline 7 & Chhaling & 20 & $\begin{array}{l}\text { Springs and } \\
\text { Streams }\end{array}$ & 366000 & 8 & $\begin{array}{l}\text { Springs } \\
\text { and } \\
\text { Streams }\end{array}$ & \multicolumn{2}{|c|}{ Seasonal } & 3650 & 440 \\
\hline 8 & Bageshwori & 15 & $\begin{array}{c}\text { Springs, } \\
\text { Streams and } \\
\text { GW }\end{array}$ & 85500 & 5 & $\begin{array}{l}\text { Springs } \\
\text { and } \\
\text { Streams }\end{array}$ & \multicolumn{2}{|c|}{ perennial } & 9700 & 5950 \\
\hline 9 & Nagarkot & 23 & $\begin{array}{l}\text { Springs and } \\
\text { Streams }\end{array}$ & 65500 & 2 & Springs & \multicolumn{2}{|c|}{ Perennial } & 1500 & 1200 \\
\hline 10 & Sudal & 11 & Springs & 96000 & 22 & Streams & \multicolumn{2}{|c|}{$\begin{array}{l}\text { Perennial } \\
\text { and } \\
\text { Seasonal }\end{array}$} & 19625 & 8525 \\
\hline 11 & Chittapol & 14 & $\begin{array}{l}\text { Springs and } \\
\text { Streams }\end{array}$ & 101500 & 19 & Streams & \multicolumn{2}{|c|}{$\begin{array}{c}\text { Perennial } \\
\text { and } \\
\text { Seasonal }\end{array}$} & 9670 & 4820 \\
\hline 12 & Tathali & 10 & $\begin{array}{c}\text { Springs, } \\
\text { Streams and } \\
\text { Stone spouts }\end{array}$ & 480000 & 15 & Streams & \multicolumn{2}{|c|}{$\begin{array}{l}\text { Perennial } \\
\text { and } \\
\text { Seasonal }\end{array}$} & 10950 & 5525 \\
\hline 13 & Gundu & 11 & $\begin{array}{c}\text { Springs, } \\
\text { Streams and } \\
\text { Ground water }\end{array}$ & 474000 & 5 & Streams & \multicolumn{2}{|c|}{ Perennial } & 2350 & 1300 \\
\hline 14 & Balkot & 2 & $\begin{array}{l}\text { Springs and } \\
\text { Groundwater }\end{array}$ & 205000 & 3 & Streams & \multicolumn{2}{|c|}{$\begin{array}{l}\text { Seasonal } \\
\text { and } \\
\text { perennial }\end{array}$} & 4600 & 350 \\
\hline 15 & Katunje & 3 & $\begin{array}{l}\text { Springs and } \\
\text { Groundwater }\end{array}$ & 70000 & 1 & Streams & \multicolumn{2}{|c|}{ Perennial } & 1200 & 300 \\
\hline 16 & $\begin{array}{c}\text { Bhaktapur } \\
\text { Municipality }\end{array}$ & 1 & $\begin{array}{l}\text { Streams and } \\
\text { Groundwater }\end{array}$ & 3000000 & & & & & & \\
\hline 17 & $\begin{array}{c}\text { Thimi } \\
\text { Municipality }\end{array}$ & 1 & $\begin{array}{c}\text { River and } \\
\text { Groundwater }\end{array}$ & 9000000 & & & & & & \\
\hline & Total & 150 & $\begin{array}{c}\text { Water } \\
\text { Consumption }\end{array}$ & 15639200 & 127 & $\begin{array}{l}\text { Lan } \\
\text { Irriga }\end{array}$ & & $101^{7}$ & & 44050 \\
\hline
\end{tabular}


from Hanumante River and its tributaries is estimated to be 142,065,000 litres (Figure 2) which is 9 times more than water extraction for domestic purpose in Hanumante basin of Bhaktapur district.

The level of water flow in Hanumante is low from November to April. This is the period when competition for the river water in different uses intensifies. This is also the period when major share of this flow is abstracted for agricultural uses in the upstream. The brick industries, with the work of brick casting concentrating during the dry season also abstract significant amount of water. Since the available flow in the river is low, the brick industries construct temporary earthen dam in the river to create pounding of water so that water from the river could be pumped using low lift centrifugal pumps. The farmers who depend on the river water for irrigation by pumping the river water seem to have informal arrangement with the brick industries for the sharing of limited river water in the dry season. In the need of water for irrigation they ask the brick industries to open up the earthen dam built for pounding of water, so that water would flow on the downstream and can be pumped from desired site or ask the factory owner to pump the river water to irrigate their field if the land is seasonally given in lease to the concerned industry. Except some occasional debate, this arrangement has not produced large scale conflict among these two groups of users. However, irrigation use of water by the downstream farmers generally gets delayed due to water abstraction by the brick factories and therefore they always have grievances against the brick factories.

Whatever limited water flows further downstream, a major share of this flow is abstracted by the farmers by pumping river water for vegetable cultivation in the fringe area of Bhaktapur and Madhyapur Thimi municipalities. This virtually leaves very little water flowing downstream during the dry season. The minimum requirement of 30 percent environmental flow is also not maintained in the river which clearly reveals that the sustainability and health of river ecology is in question mark.

\subsection{Implications of Uses and Competition over River Water}

Water flow on the downstream of Hanumanghat during the dry season is essentially sewerage flow and liquid wastewater disposal into the river at different locations and the contributions of groundwater. This is the reason that river progressively gets polluted beyond Hanumanghat. Wastewater and sewage disposal into the river begins only after the river enters into the urbanized areas of the city. River pollution due to increasing effluent discharge becomes apparent only after Liwali Town Planning area due to concentrated flow of effluents into the river.

There are numerous water polluting industries, small as well as large, located within the city of Bhaktapur. A summarized list of these industries is provided in Table-3. These industries use water for different processes. Although, all these industries do not extract river water directly and either depend on groundwater or water from municipal drinking water supplies, wastewater produced in these industries is disposed in Hanumante River either directly or through the municipal sewerage system. Local Self Governance Act 1999 (2055 B.S) has given authority to the VDCs and Municipalities to ensure water conservation and management at the local level. Section 28 of the act provides that the VDC shall be responsible for protecting source of water and environment and same also applies in the case of municipalities. The act states that the Municipality may impose a larger fine up to NRs.15, 000 and NRs. 100 in case of VDC, for dumping of solid waste into or near the water bodies and realize the expenses incurred in removing the waste (WaterAid Nepal, 2005). The industries in disposing their liquid waste into the river have been completely disregarding the provisions of this act and Bhaktapur Municipality seems to be lacking mechanisms in enforcing the provisions of this act. Instead the Municipality itself has been dumping the daily loads of solid waste alongside of the river and discharging the domestic sewage of entire city into Hanumante River. 
At present Hanumante River at the downstream of Hanumanghat has turned into a virtual sewerage. The river pollution has reached to the extent the water is no longer suitable for human uses except for using the river as waterway for domestic and industrial effluents. On the downstream, beyond the bridge at Sallaghari, the use of river is limited to effluent discharge of the industries located along the river course in Thimi.

Table 3: Types of Water Polluting Industries

\begin{tabular}{|l|l|c|}
\hline S.N & Type of industries & Number \\
\hline 1 & $\begin{array}{l}\text { Agriculture equipments } \\
\text { production }\end{array}$ & 3 \\
\hline 2 & Carpet production & 47 \\
\hline 3 & Cement block production & 1 \\
\hline 4 & Cloth production & 16 \\
\hline 5 & Color lab & 8 \\
\hline 6 & Cotton and woolen shawl & 14 \\
\hline 7 & Dairy & 15 \\
\hline 8 & Garment & 16 \\
\hline 9 & Glycerin packaging & 1 \\
\hline 10 & Hair oil production & 1 \\
\hline 11 & Health service & 7 \\
\hline 12 & Hosiery production & 1 \\
\hline 13 & Ink production & 1 \\
\hline 14 & Juice production & 1 \\
\hline 15 & Lime production & 1 \\
\hline 16 & Metal industries & 20 \\
\hline 17 & Mineral water production & 6 \\
\hline 18 & Pashmina production & 15 \\
\hline 19 & Phenyl production & 1 \\
\hline 20 & Pig keeping & 2 \\
\hline 21 & Pipe production & 4 \\
\hline 22 & Plastic materials & 4 \\
\hline 23 & Plywood industries & 1 \\
\hline 24 & Soap production & 11 \\
\hline 25 & Stationery production & 19 \\
\hline 26 & Textile production & 1 \\
\hline 27 & Thread coloring & 11 \\
\hline 28 & Tiles production & 3 \\
\hline 29 & Turpentine oil & 1 \\
\hline & Total & $\mathbf{2 3 2}$ \\
\hline & Sorce: & \\
\hline
\end{tabular}

(Source: Modified from DCSSI, 2009)

Use of wastewater for irrigation has been the most significant river water use on the downstream of
Sallaghari. The farmers using the river water for irrigation have been those who are traditionally dependent on Hanumante River for irrigation. These farmers do not have other option for irrigation and continue to use river water for irrigation.

The water uses in Hanumante River has definite spatial pattern as illustrated in Figure 3. In the upstream of Hanumanghat, the water use is essentially for domestic uses, irrigation and the water extraction in the brick industries. The river course located in the city of Bhaktapur, the use of the river is limited to the disposal of solid and liquid waste disposal. Most of the places of religious and cultural importance are also located along the river course in this reach of the river. On the downstream, use of waste water for irrigation has been the dominant use of river water.

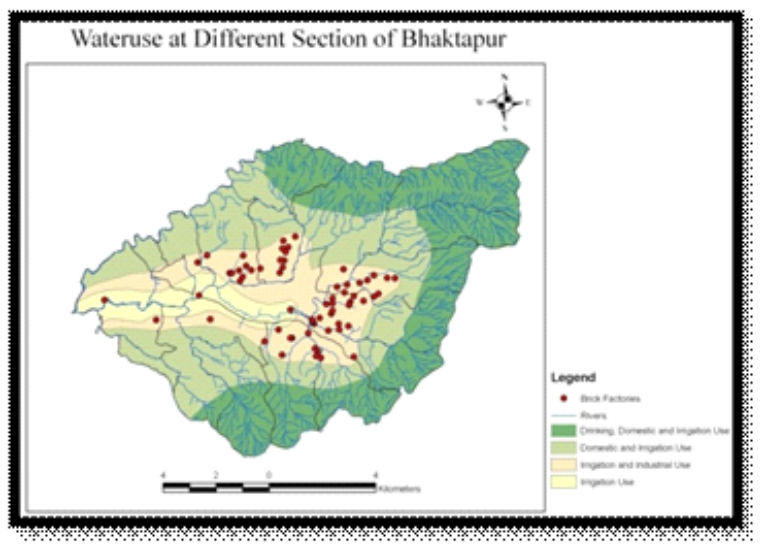

Fig.3. Schematic Spatial distribution of existing water use in Bhaktapur

\section{Conclusion and Recommendations}

Hanumante River has been important source of water in Bhaktapur district for diversified uses. The river carries immense social, economic, religious and cultural importance and has been the means of agricultural based livelihood for the people who have been traditionally depending on the river water for irrigation. Low water flow period in the river is also the period when competition for river water in different uses intensifies. During this period, water extraction for agricultural uses in upstream of the river, brick industries and direct pumping of water for vegetables cultivation in urban fringes 
abstracted major share of flow in Hanumante. Water flow on the downstream of Hanumanghat during the dry season is essentially sewerage flow and liquid wastewater disposal into the river at different locations and limited contribution of groundwater.

Rampant abstractions of river water seriously reduce the downstream flow, thus, critically affecting the river ecology on the downstream. The importance of environmental flow for the sustained ecology of the river has clearly revealed from the study of Hanumante River. Riverside plantation should be carried out in order to maintain the river ecology and aesthetic beauty of its surrounding. Beside this, river water users should be responsible for river conservation and hence mechanism of payment for ecological services provided by the river should be developed.

\section{References}

[1] DCSSI, 2009. List of Industries in Bhaktapur. Department of Cottage and Small Scale Industries (DCSSI), Bhaktapur, Nepal.

[2] DDC, 2010. District Profile Bhaktapur. District Development Committee (DDC), Bhaktapur.

[3] nec, 2008. Research proposal for Studying Hanumante River Basin. Interdisciplinary Water Resources Management Programme, Nepal Engineering College (nec), Bhaktapur, Nepal.

[4] Pant P.R. and D. Dongol, 2009. Kathmandu Valley Profile: Briefing Paper. Governance and Infrastructure Development Challenges in the Kathmandu Valley, Kathmandu, Nepal.

[5] Water Aid Nepal, 2005. Water Laws in Nepal: Relating to Drinking Water, Sanitation, Irrigation, Hydropower and Water Pollution. 